\title{
Lexis
}

Journal in English Lexicology

$10 \mid 2017$

The Expression of Intensity

\section{Intensity, reduplication, and pluractionality in Ancient Greek}

\section{Elisabetta Magni}

\section{CpenEdition}

Journals

\section{Electronic version}

URL: http://journals.openedition.org/lexis/1117

DOI: $10.4000 /$ lexis. 1117

ISSN: 1951-6215

\section{Publisher}

Université Jean Moulin - Lyon 3

\section{Electronic reference}

Elisabetta Magni, « Intensity, reduplication, and pluractionality in Ancient Greek », Lexis [Online], 10 | 2017, Online since 30 September 2017, connection on 20 April 2019. URL : http:// journals.openedition.org/lexis/1117; DOI : 10.4000/lexis.1117

This text was automatically generated on 20 April 2019.

\section{(c) (i) () $\Theta$}

Lexis is licensed under a Creative Commons Attribution-NonCommercial-NoDerivatives 4.0 International License. 


\title{
Intensity, reduplication, and pluractionality in Ancient Greek
}

\author{
Elisabetta Magni
}

\section{0 . Introduction}

\subsection{Intensive perfects in Archaic Greek}

1 According to Bolinger [1972: 15], the notion of intensity is "commonly associated with adjectives and adverbs", but its manifestations may involve all word classes, including nouns and verbs. For instance, in the verbal system of Ancient Greek both the present and the perfect include small groups of intensive forms characterized by reduplication. These, which are generally considered as recessive, involve some unresolved questions concerning their origin, the semantics of intensity and the linguistic devices used to convey this notion. In particular, the investigation will focus on the perfect in Archaic Greek $^{1}$, a category usually marked by reduplication and with two different semantic values: the resultative, which denotes a state in the present resulting from an action in the past, and the intensive, which describes actions as ongoing processes and differs from the present only in the intensity with which the events are depicted. ${ }^{2}$ In Classical Greek resultative values gradually generalize and past meanings start to develop, while intensive meanings tend to disappear. The difference between Homeric and post-Homeric uses of the perfect is thus especially salient in this recessive class of verbs, which are often perfecta tantum with secondary presents.

2 The analysis is complicated by the fact that intensive meanings seem particularly common with the perfects of noise verbs (e.g. bébrykha 'I roar', or kéklēga 'I scream'), but there is no consensus about the other verbs to be included in the category; for instance, those describing activities of the senses like dédorka 'I gaze', or those describing feelings like gégettha 'I am happy'. These difficulties lead Chantraine [1927: 17-18] to reject the 'intensive perfect' as a separate type ${ }^{3}$, while Wackernagel [1926: 166-167], on the other 
hand, identifies several subclasses of verbs and claims that comparison with cognate languages proves that these forms are ancient and have inherited functions. ${ }^{4}$

In the same vein, Schaefer reconstructs a Proto-Indo-European inflectional category of 'intensives', which in Sanskrit (and in other languages) is continued by forms that pertain to the present system, are marked by 'heavy' reduplication (see 2.2.), denote noise or luminosity, and code mostly iterativity rather than intensiveness (Schaefer [1994: 78-99]). In agreement with this idea, Drinka [2003: 92-93] supposes that some remnant features of this archaic category have been incorporated into the Indo-European perfect, which she sees as characterized by intransitive and 'stative' values. ${ }^{5}$ For Di Giovine [2010], who denies the idea of a primitive connection between intensive and perfect, this process of inclusion is a secondary phenomenon, mostly due to formal reasons. ${ }^{6}$ In this perspective, the puzzling perfects of noise verbs are viewed as the remains of an actional category, whose inevitable decline has followed an alternative path with respect to the usual integration into the present system.

However, the issue of whether the intensive is related to the other uses of the perfect and if so, how, remains controversial and, considering the simultaneously existing functions in Archaic Greek, "one wonders by which historical coincidence two very different meanings, intensity and resultativity, were associated to the same morphology" (Gerö \& von Stechow [2003: 269]). In order to find answers to these questions, we will start from the link between intensification and reduplication.

\subsection{Intensification and reduplication}

5 In recent years, increasing interest in the typology of reduplicative constructions has attracted researchers' attention to the wide range of meanings and functions conveyed by this morphological procedure (Hurch [2005]; Rubino [2013]). As already observed by Sapir [1921: 79], the use of reduplication as a "self-evident symbolism" is often associated with concepts such as distribution, plurality, repetition, customary activity, increase of size, added intensity, continuance. In particular, according to Moravcsik [1978: 317], "the most outstanding single concept that reduplicative constructions recurrently express in various languages is the concept of increased quantity", which is in turn related to intensity "in that it involves quantity of energy investment or size of effect" (Moravcsik [1978: 321]).

6 Hence, intuitively speaking, the iconic dimension of doubling phenomena suggests an immediate relation with intensity but, on the other hand, it also evident that, when conveyed by reduplicative constructions, this notion is de facto associated with a broad constellation of values, an observation that encourages one to expand the perspective on the Homeric perfects.

7 In this respect, Haug observes that the terms 'abnormal' or 'intensive' are somewhat unhelpful and seem only "a creation of philologists startled by the apparent synonymy of the perfect and the present in such cases", however, the exact nature of their semantic content "cannot be safely read out of the texts" (Haug [2004: 404]). As we will see in what follows, the main problem with the traditional definition lies in the choice of a label that, while focusing on the problematic relation with the perfect, inevitably limits the viewpoint on the functions of these reduplicated forms and hinders the interpretation of their meanings. 
The basic idea is that, in this case, the notion of intensity is only a part of the story and that, for the purpose of this investigation intensification is to be considered as pertaining to the processes whereby speakers extend, strengthen, or multiply 'the verbal idea', that is, as part of the domain of pluractionality.

\subsection{Intensification and pluractionality}

In his seminal work, Jespersen [1924: 210-211] argued that not only entities, but also events can be quantified, and stated the necessity of a special category coding the 'plural of the verbal idea' as a parallel to nominal number. Initially labeled as 'verbal plurality', this notion has been further investigated by Dressler [1968] and Cusic [1981]. Its use has spread with the recent label of 'pluractionality' and with reference to the encoding of information about 'event plurality', mainly by means of morphological devices affecting the verb (e.g. reduplication or suffixes), or by lexical tools (e.g. adverbs or verbal periphrases). From a semantic point of view, this cross-linguistic category "should be broadly construed to include the multiplicity of actions, events, occurrences, occasions and so on; but in addition, whatever indicates extension or increase, whether in time or space, of actions or states of affairs" (Cusic [1981: 64]). ${ }^{7}$ Starting from this definition, whereby pluractionality relates to concepts such as repetition, intensity, distribution, frequency, duration, habituality and even stativity, this study explores the specific role of degree-like meanings, and the extent to which Homeric perfects can be interpreted as encoding different types of event plurality.

The paper is organized as follows: the next section provides some basic notions and terminological distinctions concerning pluractionality (1.1.), the connections with reduplication, and with lexical and verbal aspect (1.2.). Section 2 illustrates the pluractional readings of Homeric perfects characterized by intensive and distributive meanings (2.1. and 2.2.), proposes a semantic map showing the intersection between the diachronic paths of reduplication and event plurality (2.3.), and describes progressive and habitual meanings (2.4. and 2.5.). Section 3 focuses on the domain of habituality discussing attitudinal (3.1), potential (3.2), individual-level state (3.3.), and generic meanings (3.4.). The last section offers a more complete map for the meanings and functions of the Homeric perfects and provides some concluding remarks.

\section{The domain of pluractionality}

\subsection{Pluractional meanings}

In the following, we will briefly recapitulate some basic distinctions concerning the classification of pluractional meanings. According to Cusic [1981], variation in this broad domain results from the interaction of the following four parameters.

The event ratio parameter, which is the most basic distinction within pluractionality, differentiates between event-internal and event-external plural verbs. More precisely, an event consisting of a repetitive series of sub-events occurring in one and the same situation, as in (a), can be classified as event-internal pluractionality. On the other hand, a whole event repeating itself in the same occasion or in different situations, as in (b), can be classified as event-external pluractionality. Obviously, repetitivity and repetition may be also combined, as in (c): 
(a) John is coughing

(b) John kisses Mary every morning

(c) John knocked daily at Mary's door

13 As a matter of fact, the distinction between event-internal and event-external pluractionals is not always so simple, and it should be viewed as a cline rather than a sharp division, while the other parameters serve to cross-classify the meanings between these two main categories.

The relative measure parameter concerns in fact the relative size of the repetitions, or other related notions such as the efficacy of result, the degree of effort, etc. In particular, when it is the effort of an action, rather than its size or result that is at issue, we obtain the intensive reading, which is of peculiar relevance for the following discussion and denotes "increased effort or increased quantity of the action" [Cusic 1981: 84].

The connectedness parameter further specifies the general 'repeated action' reading by focusing on the "distinctness of the iterated units of action", which can be continuous or discontinuous (Cusic [1981: 99]).

Eventually, the distribution parameter defines the pluralization of events as due to distribution over plural times, spatial locations and participants, with the latter further dividing in subject and object distributive, which are not mutually exclusive.

\subsection{Pluractionality and reduplication}

17 Considering the issue of pluractional marking on the verb, cross-linguistic research reveals that there is considerable variation, and that one of the most widespread strategies is reduplication (Rubino [2013]). With this in mind, it is therefore tempting to test a 'pluractionality-based' analysis of the Greek perfects, where reduplication is an ancient and obligatory (though not specific) feature (Di Giovine [1996: 126]). ${ }^{8}$

On the whole, reduplicative markers attested in historical languages show two distinct forms and functions (Di Giovine [1996: 102-103]):

i) the repetition of the whole structure of the verb root (or of a 'heavy' syllable), which usually adds an iterative-intensive Aktionsart (e.g. pres. bambáinō 'stutter', marmáirō 'glitter') and is recessive;

ii) the copying of the first consonant of the root followed by a short vowel, which usually distinguishes themes from different inflectional and aspectual categories (e.g. pres. gígnomai vs. perf. gégona 'born, become'), and tends to become dominant.

Although the reconstruction of a specific value for reduplication remains a thorny problem, its much-debated connections with notions such as iterativity and durativity, or with stativity and perfectivity (Di Giovine [1996: 116-118]), highlight an interesting ambiguity between the domains of lexical and verbal aspect. Not surprisingly, in the literature on pluractionality the relation with these categories is also frequently discussed; in this respect, many scholars view pluractionality as a subtype of Aktionsart (Dressler [1968]; Cusic [1981]; Xrakovskij [1997]; Wood [2007], while others focus on the interaction with verbal aspect (Shluinsky [2009]; Bertinetto \& Lenci [2012]). For the purpose of this study, interesting suggestions concerning the multiple connections between reduplication, pluractional meanings and actional/aspectual values can be found in the cross-linguistic paths for the grammaticalization of reduplicative markers proposed in Bybee, Perkins \& Pagliuca [1994: 172] and illustrated in figure 1: 
Figure 1: Cross-linguistic paths of reduplication

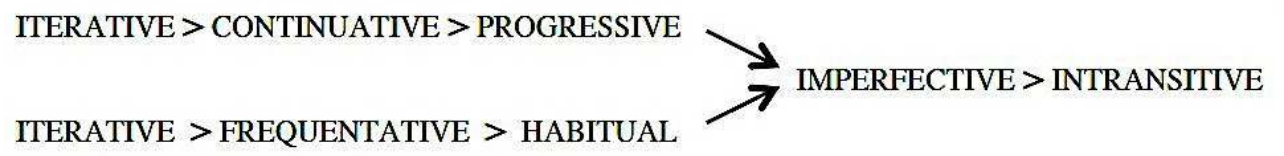

Drinka [2003: 94-95] discusses this schema, suggesting that the early Indo-European intransitive perfects could be located on the right side, as grammaticalized forms with reduced reduplication. However, it is not clear how forms coding iterativity with 'heavy' reduplicative markers "could have introduced reduplication to the perfect system" (Drinka [2003: 95]), and how they relate with the intermediate steps of the process.

In the next section, some of these issues will be clarified by completing the map and by exploring the range of values conveyed by the Homeric perfects. To this end, we must remember that the expression of pluractionality mobilizes diverse devices; in fact, apart from reduplication and affixes, speakers may also use free morphemes and lexical tools. These strategies "are not mutually exclusive, neither paradigmatically (for one and the same language may present, e.g., affixes and periphrases) nor syntagmatically (for one and the same sentence may exhibit, for example, both dedicated affixes and frequency adverbials)" (Bertinetto \& Lenci [2012: 853]). In addition, the context as well may occasionally suggest pluractionality by mere pragmatic inference.

Therefore, although the relation between pluractional meanings and reduplication is a well established one, in order to avoid circular reasoning, in our examination of Homeric perfects we will try to ascertain their readings by checking for the presence of supplementary devices such as the adverbials (adverbs expressing durativity, frequency, intensity, etc.), or the contextual cues (multiple participants, pragmatic inferences, etc.).

\section{The Homeric Perfects}

\subsection{Noise verbs}

24 As to be expected, this operation is rather straightforward with the verbs of noise, whose Aktionsart is naturally related to repetitive and continuous actions, but whose use often expresses repeated and distributed actions as well. In the following, we will propose a couple examples for each verb, but there are dozens of similar passages involving reduplicated forms (including pluperfects and aorists). ${ }^{9}$

Considering the perfectum tantum bébrykha 'to roar, bellow' in example (1), we can infer that the event has an intensive reading because the wave is thunderous (rhóthion), but at the same time it surely has a distributive reading over space because the sound repeats all around (amphi), in different places. These meanings also seem appropriate for the pluperfect in (2), which describes the dangerous passage between the mythical sea monsters Scylla and Charybdis:

(1) [...] amphì dè kŷma

bébrykhen rhóthion [...]

'all around the wave

is roaring thunderous'

(Od. 5, 411-412) 
(2) $[\ldots]$ amphì dè pétrēe

deinòn bebrýkei [...]

'all around the rock

was terribly roaring'

(od. 12, 241-242)

in the examples with the participles of the perfectum tantum lélêka 'scream, shriek', the intensity of the action is stressed by the adverbs deinòn 'terribly' in (3), and oxỳ 'loudly' in (4):

(3) éntha d' ení Skýllē náiei deinòn lelakŷia

'therein dwells Scylla, yelping terribly'

(Od. 12, 85)

(4) [...] ho d' engýthen oxỳ lelēkòs

tarphé' epaíssei, [...]

'but [the falcon] shrilling loudly

follows close after [the dove]'

(Il. 22, 140-141)

The uses of the perfecta tantum mémyka 'roar, rumble' and mémēka 'baa, bleat' again suggest intensity in examples (5) and (7), and distribution over space in examples (6) and (8):

(5) tâuron erýgmelon ekhétēn, ò dè makrà memykò̀s

hélketo $[\ldots]$

'[two lions] were holding a loud-lowing bull and he, bellowing mightily,

was drawn'

(Il. 18, 580-581)

(6) kalòn aoidiáei, dápedon d' hápan amphimémyken

'[Circes] sings beautifully, and all the country is echoing around'

(Od. 10, 227)

(7) azēkhès memakŷiai akúusai ópa arnôn

'[many thousand ewes] bleating incessantly in answer to the bleating of their

lambs

(Il. 4, 435)

(8) thếleiai dè mèmēkon anếmelktoi perì sēkús

'the ewes were bleating unmilked around the pens'

(Od. 9, 439)

The values of intensity and distribution over time, space and participants are evident for the participial forms of the perfect kéklēga (pres. klázō) ‘scream' as well:

(9) bề dè dià promákhōn kekorythménos áithopi khalkô oxéa keklégōn, [...]

'Then he strode forth amid the foremost fighters, harnessed in flaming

bronze,

crying acutely'

(Il. 17, 87-88)

(10) hồs hoi keklégontes ep' alléloisin órusan

'[Sarpedon and Patroclus] rushed screaming towards each other'

(Il. 16, 430)

(11) [...] âipsa gàr êlthe

keklēgòs Zéphyros, megálē sỳn láilapi thýōn

'for immediately came

shrieking the West Wind, blowing with a furious tempest'

(od. 12, 407-408) 
'screech, twitter', in (12) and (13):

(12) énth' hó ge tùs eleeinà katếsthie tetrigôtas,

mêtēer d' amphepotâto odyroménē fíla tékna

'Then [the snake] devoured them [the little sparrows] as they twittered

piteously

and the mother fluttered around them, wailing for her dear little ones'

(Il. 2, 314-315)

(13) ò̀s hai tetrigŷiai hám' ếisan [...]

'so [like bats, the souls] were going shrieking together'

(od. 24, 9)

In the preceding examples, the verbs reproducing noises, animal sounds, or human shouts represent the core of the 'intensive perfect' as traditionally described. According to Tichy [1983: 63-71], reduplicated onomatopoeic forms are also the archetype of the 'intensive' in the proto-language, but the relevance of the notion of iterativity in presents denoting luminosity (Schaefer [1994]) and the meanings of Homeric perfects suggest that the category goes beyond the imitation of sounds. Therefore, in order to check whether the link between reduplication and the notions of repetition, intensity and distribution leads to a more plausible account of the phenomena, it will be useful to look at some further examples.

\subsection{Beyond the noise}

Considering other types of verbs, we observe that intensity is intrinsically relevant to the interpretation of the perfect dédorka (pres. dérkomai) 'gaze, glare', which in (14) occurs with the adverb smerdaléon 'terribly':

(14) smerdaléon dè dédorken helissómenos perì kheiê 'and [the snake] glares terribly, coiled around his lair' (Il. 22, 95)

Analogous considerations apply to the perfectum tantum mémona 'be very eager', which in (15) and (16) combines with the adverb málista 'as much as possible':

(15) kài gàr pollòn áristos anèr mémonén te málista mētér' emè̀n gaméein kài Odyssêos géras héxein

'For he is by far the best man, and is most eager to marry my mother and to have the honor of Odysseus'

(od. 15, 521-522)

(16) [...] málista dè pháidimos Héktōr

helkémenai mémonen [...]

'and glorious Hector is most eager

to drag [Patroclus] away'

(Il. 18, 175-176)

The use of the perfect dédēa (pres. dáiō) 'burn, blaze, flame' however denotes distribution over space in examples (17) and (18):

(17) pántē gár se perì stéphanos polémoio dédēe

'for on every side around you blazes a circle of war'

(Il. 13, 736) 
(18) [...] séo d'héinek' aütế te ptólemós te

ásty tód' amphidédēe $[$ [...]

'and it is because of you that the battle-cry and the war

are blazing around this city'

(Il. 6, 328-329)

34 The perfect órōra (pres. órnymi) 'arise, stir,
both intensive and distributive readings:

(19) allếlus olékusi, boè d' ásbestos órōren

'they are slaying one another, and the cry goes up unquenchable'

(Il. 11, 530)

(20) [...] udé ti ôide

péntheos, hósson órōre katà stratón $[$ [...]

'nor does he know

about all the grief that is arising throughout the camp'

(Il. 11, 657-658)

Lastly, even the participial forms of péplēga (pres. plêssō) 'hit' describe plural events with added intensive meanings, in (21), or with frequentative and distributional readings over space and time, in (22), or participants, in (23):

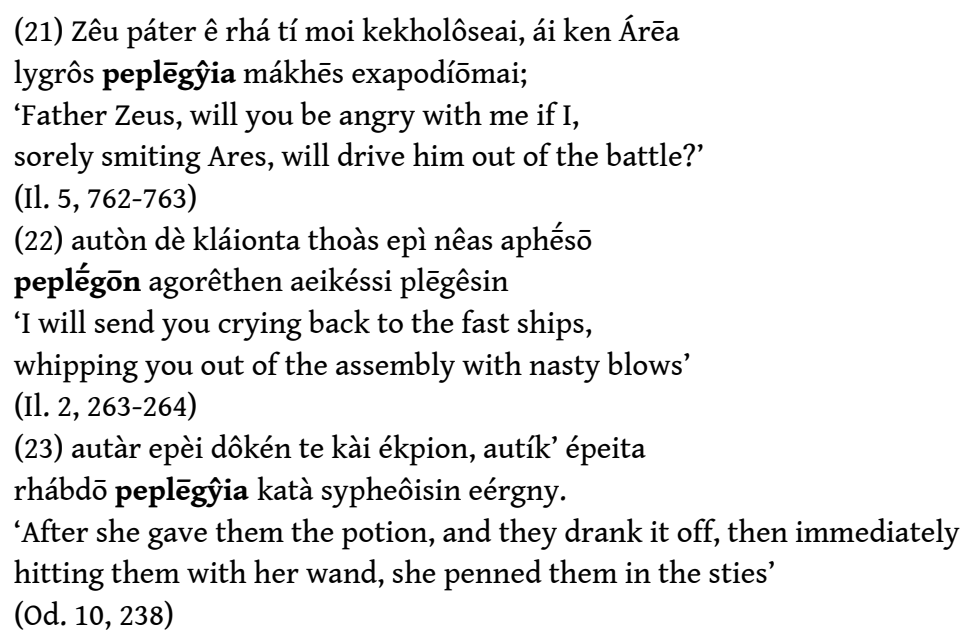

So far, all the Homeric examples confirm the striking similarity between the meanings expressed by reduplicated forms and the typical meanings of pluractional verbs. Accordingly, we may say that the essential semantic component of these forms was plurality and not intensity; more precisely, their basic value concerns event repetition, which is further and contextually specified by additional intensive and/or distributive meanings.

\subsection{Intensive and Distributive}

As we have seen in 1.1, intensive and distributive values amount to Cusic's relative measure and distribution parameter respectively. On closer inspection, both intensity, which associates with continuous single events, and distribution, which associates with discontinuous serial events, interact with the event ratio parameter along the cline between repetitive and repeated actions. In fact, "all the repetitive types can be considered continuous or connected, since they represent single events, and the repeated types discontinuous, since they represent (in some cases) serial events" (Cusic [1981: 96]). 
Therefo, considering that the grammaticalization paths illustrated in figure 1 include the notions of continuative (above) and frequentative (below), we can assume that the semantic development of reduplication intersects orthogonally with the meanings ranging between the two poles of event-internal and event-external pluractionality. This is illustrated in the provisional map in figure $2:{ }^{10}$

Figure 2: Intersections between the paths of reduplication and pluractional meanings

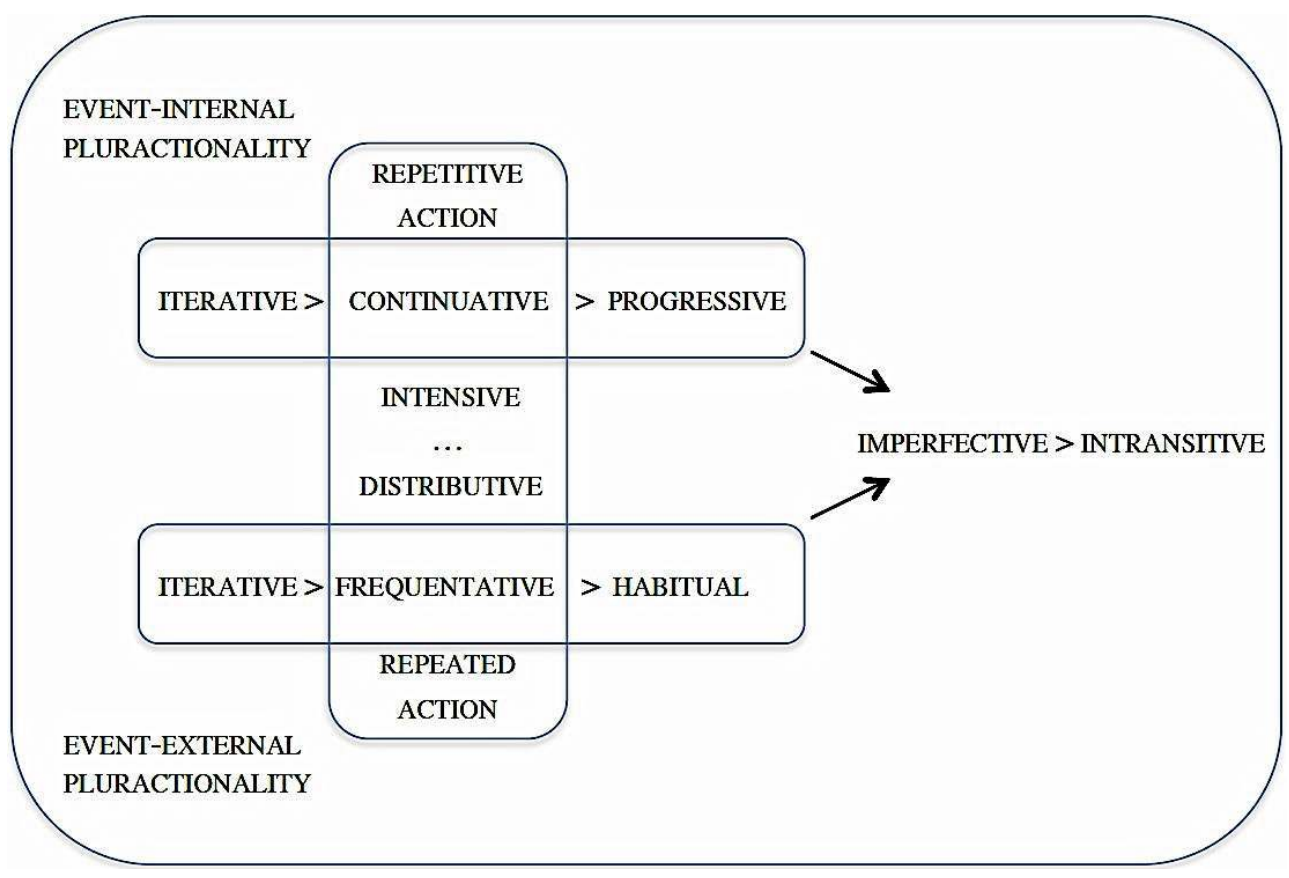

Iterativity can associate with iconic reduplication in verbs belonging to iterative Aktionsart and lexicalized with such specific meanings: this is the case of the presents like bambáinō and marmáirō (see 1.2.), which one might situate on the left of the map.

In other cases, iterativity is associated with the presence of a pluractional marker that conveys the basic meaning of event repetition and additional intensive or distributive values: this is the case of the Homeric 'perfects with present meaning', which one might situate at the core of the intersection in the middle of the map. With certain verbs, the transition from 'iteration' (e.g. repetitive sound) to 'iteration + intensification' (e.g. repetitive sound that grows progressively louder) has led to lexicalized forms in which plurality and degree effects co-occur. These are the perfecta tantum that, like the English pluractionals stutter or knock do not have simplex counterparts, and can be seen as the nucleus from which reduplication starts to develop further pluractional meanings.

41 As explained in 2.2, the recessive type of reduplication is mainly related to iterativity and lexical aspect, while the more productive type, which here signals repetition plus additional meanings, is also associated with verbal aspect. The fact that aspectual notions, event plurality and degree effects can all be conveyed by reduplication corroborates the view that there is a natural connection between these domains.

At this point, in order to complete the map and explain the interplay between verbal plurality and verbal aspect, we must illustrate the details of the converging paths connecting both progressive and habitual meanings to the domain of imperfectivity. 


\subsection{From Progressive to Imperfective}

43 As for the label Progressive (i.e. ongoing action), it is worth mentioning Dressler's [1968: 60] and Xrakovskij's [1997: 4 and 8] observations that plurality and duration are strictly related. In addition, in their discussion of paths of reduplication leading towards the expression of imperfectivity, Bybee, Perkins \& Pagliuca [1994: 171] observe that: "imperfective forms are typically used in backgrounded clauses where the focus is on the situation as continuing (while something else occurs) and not on the outcome of the situation with respect to a particular object. For this reason, backgrounded clauses are often intransitive as well as imperfective".

In the light of these considerations, it is not surprising that many 'intensive perfects' are attested mainly or exclusively in the participle form (Schwyzer \& Debrunner [1950: $263 \mathrm{n}$. 1]), and that in our examples they usually denote an event that continues in the background while the main action (often implying motion verbs) proceeds in the foreground, as in examples (4)-(5), (9)-(13), and (21)-(23). Observing the semantic map in figure 2 , the frequent use of participles seems to reflect the increasing correlation between reduplicated pluractional forms and durativity/imperfectivity.

Moreover, the fact that the early Greek perfect is essentially intransitive is in keeping with the final step on the path, and this is perfectly plausible if we consider that: "verbal pluralization transforms a telic event (e.g., semelfactive, achievement, accomplishment) into an atelic event (e.g., activity)" (Yu [2003: 309]), because the endpoint of pluralized events (or the number of iterations) is often left unspecified.

Atelic is in fact the kind of perfect that, with respect to the present, encodes the intransitive counterpart in anticausative alternations like tếkō/tétēka 'melt', tréphō/ tétropha 'condense, coagulate', etc. In a similar way, the notions of atelicity and progressivity are also relevant to those 'perfects with present meaning' that describe gradual and spontaneous changes of state, like gégètha 'become happy', bébritha 'become heavy', téthēla 'blossom', péphrika 'horripilate', etc. (Magni [2010]). ${ }^{11}$ From our point of view, these are not 'true' perfects but pluractionals whose replication signals additional aspectual values.

\subsection{From Habitual to Imperfective}

Another source for the imperfective is found in habitual meanings, which can be illustrated by the uses of mémēla (pres. mélō) 'concern'. In (24) the frequency adverb (âu 'again') suggests repetition, but in (25) this basic pluractional value is not so relevant, and the situation described seems rather to be a habitual state (aièn 'always').

(24) skhétlie, kài dè âu toi polemếia érga mémēle

kài pónos $[. .$.

'Rash man, now you are again involved in the deeds of war

and in struggle'

(od. 12, 116-117)

(25) [...] hê t'aièn aếsyla érga mémēlen

'[Athena] who is always involved in some impious action'

(Il. 5, 876) 
Recent studies point out that in fact habituality is a complex domain that displays semantic and functional overlaps with pluractionality. According to Shluinsky, habitual, attitudinal, potential, individual-level and generic meanings cluster around the aspectual notion of imperfectivity. In addition, since they involve predicates denoting stable features, they "are semantically and/or pragmatically related to iteration", and are "typically expressed by the same markers as are plural events" (Shluinsky [2009: 175]). Bertinetto and Lenci group these notions into a category called 'gnomic imperfectivity', which in their paper is portrayed as intersecting pluractionality (Bertinetto \& Lenci [2012: 876]).

The next section discusses the labels proposed by these scholars, and illustrates the corresponding meanings and functions as reflected in a number of Homeric examples where the use of perfective forms with present meaning is traditionally considered 'abnormal'.

\section{The domain of habituality}

\subsection{Attitudinal (and Usitative)}

The label Attitudinal refers to the meaning of a pluractional marker used "to express a basic characteristic of an individual that becomes apparent in specific regular events" (Shluinsky [2009: 182]). This can be illustrated by the use of (par)mémblōka (pres. blốskō) 'go (beside)' in example (26):

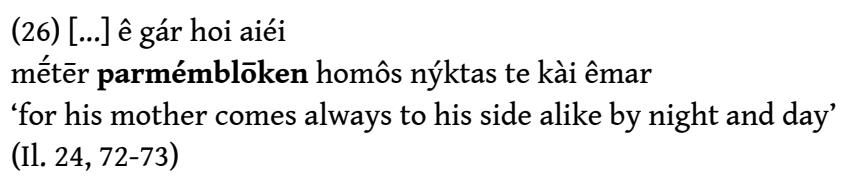

51 The following examples with déidoika 'fear' (cf. also the ancient perfectum tantum déidia) and pépoitha (pres. péithō) 'trust' instantiate the more specific Usitative meaning, which "corresponds to an event that takes place under a certain condition" (Shluinsky [2009: 177]):

(27) allà kài hồs déidoike Diòs megáloio keraunòn deinến te brontến, hót' ap' uranóthen smaragếsē 'but even he [Ocean] fears the lightning of great Zeus, and his dread thunder, whenever it crashes from heaven' (Il. 21, 198-199)

(28) autòs mèn néos eimì kài ú pō khersì pépoitha ándr' apamýnasthai, hóte tis próteros khalepếnē 'I am young and yet I cannot trust my arms to repel a man, when someone attacks first' (Od. 16, 71-72)

(29) ê ti kasignếtois epimémpheai, hôisí per anèr marnaménoisi pépoithe, kài ei méga nêikos órētai 'or you should blame your brothers, in whose fighting a man trusts, even if a great strife arises' (Od. 16, 97-98) 


\subsection{Potential}

The potential meaning expresses "the permanent capacity of an individual to perform a certain event", which is pragmatically related to iteration: "if one repeatedly takes part in an event, it means that this person (or device) is capable of doing it" (Shluinsky [2009: 176]). This seems the appropriate reading for the forms kékhanda 'contain, hold', kékeutha 'hold, hide', and dedáéka 'learn, teach' in the following examples:

(30) [...] ápyron katéthēke lébēta

kalòn téssara métra kekhandóta, [...]

'he set forth a cauldron untouched by fire,

a fair one that can hold four measures'

(Il. 23, 267-268)

(31) [...] háma d'amphìs Akhaiôis

áll' apodássesthai hósa te ptólis hếde kékeuthe

'with the Achaeans

we will make due division of all that this city may hold'

(Il. 22, 117-118)

(32) dêute fíloi, tòn xêinon erốmetha éi tin' áethlon

ôidé te kài dedáéke [...]

'Come, friends, let us ask the stranger whether

he knows and can teach any contests'

(Od. 8, 133-134)

\subsection{Individual-Level State}

Individual-Level State "is the label for the meaning of a pluractional marker that, combined with a lexical individual-level predicate, expresses a single permanent state. In this case, the resulting form is automatically an individual-level predicate, and the connection to iteration is the most obscure" (Shluinsky [2009: 176]). This happens in fact with the perfectum tantum éiotha 'be used to' in (33) and (34):

(33) Antínoos d' éiōthe kakôs erethizémen aièi mýthoisin khalepôisin, [...]

'Antinous is always used to provoke to anger in evil wise with harsh words'

(Od. 17, 394-395)

(34) hế e málist' éiōthe kakês odýnēsi pelázein

'[Athena] who above others is always used to bring sore pain upon him' (Il. 5, 766)

\subsection{Generic}

Generic "is the label for the meaning of a sentence (and a pluractional or aspectual marker used in this sentence) that introduces a permanent state of affairs. This state of affairs is a generalization of different repeated events with different individuals. [...] is used to characterize a permanent feature not of a single individual, but of a whole class of individuals" (Shluinsky [2009: 176]).

Examples are easy to find, for instance with péphy $(k) a$ (pres. phýō) 'grow': 
(35) krếnē hypò spéius perì d'áigeiroi pephýasin 'a spring beneath a cave, and round about it poplars grow' (Od. 9, 141)

(36) éntha dè déndrea makrà pephýkasi tēlethóōnta 'Therein grow trees, tall and luxuriant'

(Od. 7, 114) (Kučera [1981: 181]), and that the emergence of imperfective and stative values involves bleaching of the connection with iteration and increasing ambiguity in the use of reduplicative morphemes as pluractional markers or aspectual markers.

Figure 3: Intersections between reduplication, pluractionality and habituality

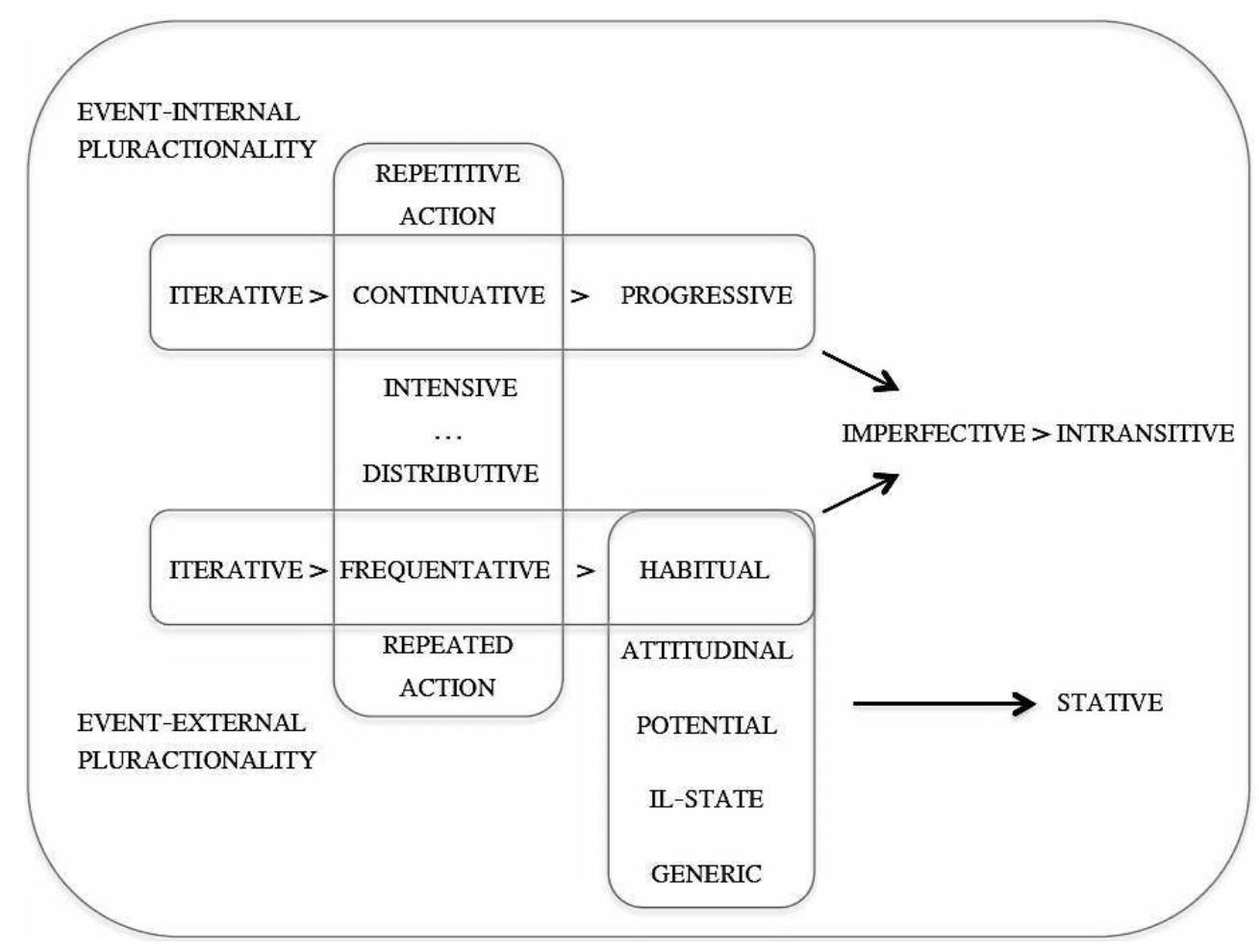

\section{Conclusions}

The above map depicts the meanings and functions of the Homeric 'perfects with present meaning' as covering various steps along the paths that in Archaic Greek involve the remnants of a "reduplicating formation coding iterativity in the ancient layers of the proto-language" (Drinka [2003: 92]). More precisely, the presents with 'heavy' reduplication, which denote the iterative Aktionsart in an iconic way, can be imagined on the left of the map, while the forms with 'light' reduplication, which code basic pluractional values, start to grammaticalize new functions by intersecting the continuative and frequentative aspect in the middle of the map. 

investigation of the Greek 'intensive perfect' has shown the limits of this traditional label, which in fact captures only a part of the phenomena involved. The discussion has shown that intensification associated with the verb often goes hand in hand with pluralization, and that the view of intensity as one of the additional meanings usually found with event plurality provides the means for explaining not only the group of noise verbs but also a wider set of Homeric forms. In this perspective, the puzzling category of 'perfects with present meaning' can thus find a unifying explanation and a significant place in the evolution of the Greek perfect. 


\section{BIBLIOGRAPHY}

BERTINETTO Pier Marco \& LENCI Alessandro, 2012, "Habituality, Pluractionality, and Imperfectivity", in BINNICK Robert I. (ed.), The Oxford Handbook of Tense and Aspect, Oxford: Oxford University Press, 852-880.

BOLINGER Dwight, 1972, Degree Words, The Hague: Mouton.

BYBEE Joan, PERKINS Revere \& PAGLIUCA William, 1994, The Evolution of Grammar: Tense, Aspect and Modality in the Languages of the World, Chicago: University of Chicago Press.

CABREDO-HOFHERR Patricia \& LACA Brenda (eds.), 2012, Verbal Plurality and Distributivity, Berlin: de Gruyter.

CHANTRAINE Pierre, 1927, Histoire du parfait grec, Paris : Champion.

CusIC David D., 1981, Verbal Plurality and Aspect. PhD thesis, Stanford University.

DI GIOVINE Paolo, 2010, "Declino di una categoria flessionale: l'intensivo in greco antico", in PUTZU Ignazio et al. (eds.), La morfologia del greco tra tipologia e diacronia. Atti del VII Incontro internazionale di linguistica greca, Milano: Franco Angeli, 189-203.

DI GIOVINE Paolo, 1990, Studio sul perfetto indoeuropeo, vol. 1, Roma.

DI GIOVINE Paolo, 1996, Studio sul perfetto indoeuropeo, vol. 2, Roma.

DRESSLER Wolfgang, 1968, Studien zur verbalen Pluralität: Iterativum, Distributivum, Durativum, Intensivum in der allgemeinen Grammatik, im Lateinischen und Hethithischen, Wien.

DRINKA Bridget, 2003, “The development of the perfect in Indo-European. Stratigraphic evidence of prehistoric areal influence", in ANDERSEN Henning (ed.), Language Contacts in Prehistory: Studies in Stratigraphy, Amsterdam/Philadelphia: John Benjamins, 77-105.

GERÖ Eva-Carin \& VON STECHOW Arnim, 2003, “Tense in time: the Greek Perfect”, in ECKARD Regine, von HEUSINGER Klaus \& SCHWARZE Christoph (eds.), Words in Time, Diachronic Semantics from Different Points of View, Berlin/Boston: de Gruyter, 251-294.

HASPELMATH Martin, 1992, "From resultative to perfect in Ancient Greek", in ITURRIOZ LEZA José Luis (ed.), Nuevos estudios sobre construcciones resultativas, special issue of Función, 11-12: 187-224. HAUG Dag, 2004, “Aristotle's kinesis/energeia-test and the semantics of the Greek perfect”, Linguistics, 42(2), 387-418.

HOMER, [1924] 1999, The Iliad with an English Translation by MURRAY Augustus T., in two volumes, revised by WYATT William F., Cambridge, Mass.: Harvard University Press.

HOMER, [1919] 1995, The Odyssey with an English Translation by MURRAY Augustus T., in two volumes, revised by рімоск George E., Cambridge, Mass.: Harvard University Press.

HURCH Bernhard (ed.), 2005, Studies on Reduplication, Berlin/New York: de Gruyter.

JESPERSEN Otto, [1924] 2007, The Philosophy of Grammar, London/New York: Routledge.

KUČERA Henry, 1981, “Aspect, markedness and t0”, in TEDESCHI Philip J. \& ZAENEN Annie E. (eds.), Tense and Aspect (Syntax and Semantics 14), New York: Academic Press, 177-189. 
MAGNI Elisabetta, 2010, “L'evoluzione semantico-funzionale dell'elemento - $\theta$ - nella morfologia verbale del greco", in PUTZu Ignazio et al. (eds.), La morfologia del greco tra tipologia e diacronia. Atti del VII Incontro internazionale di linguistica greca, Milano: Franco Angeli, 266-285.

MAGNI Elisabetta, "Pluractionality and perfect in Homeric Greek", in LOGOZzo Felicia \& POCCETTI Paolo (eds.), Ancient Greek Linguistics. New Approaches, Insights, Perspectives, Berlin/Boston: de Gruyter, forthcoming.

MORAVCSICK Edith A., 1978, "Reduplicative Constructions", in GREENBERG Joseph H. (ed.), Universals of Human Language, vol. 3. Stanford: Stanford University Press, 297-334.

NEDJALKov Vladimir P. \& JAXONTOV Sergej Je., 1988, “The typology of resultative constructions”, in NEDJALKOV Vladimir P. (ed.), Typology of Resultative Constructions, Amsterdam/Philadelphia: John Benjamins, 3-62.

NEWMAN Paul, 2013, Nominal and Verbal Plurality in Chadic, Dordrecht: Foris.

RUBINO Carl, 2013, "Reduplication", in DRYER Matthew S. \& HASPELMATH Martin (eds.), The World Atlas of Language Structures Online, Leipzig: Max Planck Institute for Evolutionary Anthropology ( http://wals.info/chapter/27).

RUIPÉREZ Martín S., 1954, Estructura del sistema de aspectos y tiempos del verbo griego antiguo: análisis funcional sincrónico, Salamanca: Colegio Trilingüe de la Universidad.

SAPIR Edward, 1921, Language. An Introduction to the Study of Speech, New York: Harcourt, Brace \& World, Inc.

SCHAEFER Christiane, 1994, Das Intensivum im Vedischen, Göttingen: Vandenhoeck \& Ruprecht. SCHWYZER Eduard \& DEBRUNNER Albert, 1950, Griechische Grammatik. Bd. 2. Syntax und syntaktische Stilistik, München: Beck.

SCHWYZER Eduard, 1939, Griechische Grammatik. Bd. 1. Allgemeiner Teil, Lautlehre, Wortbildung, Flexion, München: Beck.

SHLUINSKY Andrey, 2009, "Individual-level meanings in the semantic domain of pluractionality", in EPPS Patience \& ARKHIPOV Alexandre (eds.), New Challenges in Typology: Transcending the Borders and Refining the Distinctions, Berlin/Boston: de Gruyter, 175-197.

SICKING Christian M.J. \& STORK Peter, 1996, “The synthetic perfect in Classical Greek”, in SICKING Christian M.J. \& STORK Peter (eds.), Two Studies in the Semantics of the Verb in Classical Greek, Leiden/ New York/Köln: Brill, 119-298.

SZEMERÉNYI Oswald J. L., [1990] 1996, Introduction to Indo-European Linguistics, (transl. of Einführung in die vergleichende Sprachwissenschaft, 4 . durchgesehene Auflag, by JONES David M. \& JONES Irene), Oxford: Clarendon Press.

TICHY Eva, 1983, Onomatopoetische Verbalbildungen des Griechischen, Wien: Österreichische Akademie der Wissenschaften.

TISCHLER Johann, 1976, Zur Reduplikation im Indogermanischen, Innsbruck: Innsbrucker Beiträge zur Sprachwissenschaft.

VAN DER AUWERA Johan, 2013, "Semantic maps, for synchronic and diachronic typology", in GIACALONE RAMAT Anna, MAURI Caterina \& Molinelli Piera (eds.), Synchrony and Diachrony: A Dynamic Interface, Amsterdam/Philadelphia: John Benjamins, 153-176. 
WACKERNAGEL Jacob, 1926, Vorlesungen über Syntax mit besonderer Berücksichtigung von Griechisch, Lateinisch und Deutsch, vol. 1, Basel: Birkhäuser.

wood Esther Jane, 2007, The Semantic Typology of Pluractionality, PhD thesis, University of California, Berkeley.

XRAKOVSKIJ Viktor S., 1997, "Semantic types of the plurality of situations and their natural classification”, in XRAKOVSKIJ Viktor S. (ed.), Typology of Iterative Constructions, Münich: Lincom Europa, 3-64.

YU Alan C.L., 2003, “Pluractionality in Chechen”, Natural Language Semantics, 11: 289-321.

\section{NOTES}

1. The language of the Archaic period ( $8^{\text {th }}$ to $6^{\text {th }}$ centuries BC) is represented principally by the writings of Homer and Hesiod. With the advent of fifth-century Athenian literati begins the Classical period ( $5^{\text {th }}$ and $4^{\text {th }}$ centuries BC), followed by the Hellenistic period ( $3^{\text {rd }}$ century BC to $4^{\text {th }}$ century AD).

2. For Szemerényi [1996: 294], "In addition to state the perfect also expresses elementary actions

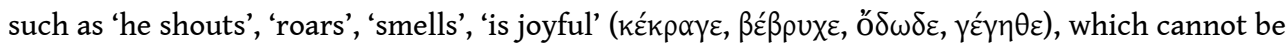
derived from resulting state but on the other hand can very well be understood as intensives". A review of the issue and further references can be found in Sicking \& Stork [1996: 125-127].

3. "Rien n'autorise à constituer une classe de parfaits intensifs comme type particulier de parfaits. La distinction est artificielle et il faut l'abandonner" (Chantraine [1927: 17]).

4. "Man kann durch Vergleichung mit dem verwandten Sprachen gerade diese Kategorie der Perfektformen als alt erweisen; es ist hier eine ererbte Verwendung" (It can be shown by comparison with cognate languages that this category of perfect forms in particular is old, and that this is an inherited use.) (Wackernagel [1926: 167]). See also Ruipérez [1954: 50-52].

5. Concerning this much-debated question, most scholars agree that the perfect originally referred to a state of the subject resulting from a preceding completed action, but opinions diverge with regard to the relations with the middle voice and to the aspectual vs. actional values of the category. For a detailed investigation of the Indo-European data and bibliographical references see Di Giovine [1990] and [1996].

6. In this respect, the relevant features are: reduplication, apophonic long vowels, and predesinential - $k$ - or - $k h$ - as in kappatic or aspirated perfects (Di Giovine [2010: 199]).

7. Beside the basic works of Dressler [1968] and Cusic [1981], see also Newman [1990]; Xrakovskij [1997]; Yu [2003]; Wood [2007]; Cabredo Hofherr \& Laca [2012].

8. On reduplication in Indo-European see Tischler [1976] and the observations in Szemerényi [1996: 268-269]. For Drinka [2003: 89-90], this device "shows signs of distinct archaism alongside undeniable secondariness", e.g. its absence in the widely attested forms of *woida 'know', and the fact that only Indo-Iranian and Greek developed fully productive (and hypermarked) reduplicated perfects with o-grades.

9. The translations given throughout the paper are my own, but those provided by Murray for the Loeb editions were also consulted. The examples do not have glosses, as these are not strictly relevant for a discussion centered on the interpretation of the perfective forms.

10. For a discussion of semantic maps as accounts of both the synchronic polysemy of forms and of their gradual semantic developments see van der Auwera [2013].

11. This point, which involves the much-debated overlaps between the perfect and the middle voice (cf. Wackernagel [1926: 168]; Di Giovine [1996: 235-243]), is thoroughly discussed in Magni [forth.]. 
12. With respect to the relations between the cross-linguistic category of 'resultative' and the Greek perfect, the reader is referred to Haspelmath [1998] and Haug [2004].

13. "Der regelmäßige Typus des aktiven Perfekts auf $-k \alpha$ ist eine griechische Neubildung gegenüber der k-losen, aus dem Indogermanischen ererbten Perfektbildung" (The regular type of the active perfect in $-k \alpha$ is a Greek innovation with respect to the type without $k$-inherited from the Indo-European perfect) [Schwyzer 1939: 765]. Cf. the more ancient deidia with respect to déidoika in (27), and pephýasi(n) vs. pephýkasi in (35) and (36). The idea of a scalar expansion within the set of noise verbs is mentioned in Di Giovine [2010: 199].

\section{ABSTRACTS}

This paper deals with the manifestation of intensity in the verbal system of Ancient Greek, where both the present and the perfect include marginal and recessive groups of 'intensive' verbs marked by reduplication. These forms involve unresolved questions concerning their origin, the semantics of intensification and the linguistic devices used to convey this notion. The investigation focuses on a peculiar set of Homeric verbs that, although they are classified as perfects, describe ongoing processes and differ from the presents only in the intensity that characterizes the events. The discussion highlights the inadequacy of the label 'intensive perfect' and proposes an analysis based on the connections between intensification, reduplication and pluractionality. It will be argued that intensity can be addressed as pertaining to event plurality, and that a number of examples with 'abnormal' perfects can find a unifying explanation when interpreted as encoding different types of pluractional meanings. The semantic maps illustrating the intersections between the diachronic paths of reduplication and the domain of event plurality will clarify the functions and the evolution of the Homeric perfects.

Cet article aborde la manifestation de l'intensité dans le système verbal du grec ancien, où le présent et le parfait incluent des groupes marginaux et récessifs de verbes « intensifs » marqués par la réduplication. Ces formes impliquent des questions non résolues concernant leur origine, la sémantique de l'intensification et les moyens linguistiques utilisés pour transmettre cette notion. La recherche se concentre sur un ensemble particulier de verbes homériques qui, bien que classés comme des parfaits, décrivent des processus en cours et ne diffèrent du présent que dans l'intensité qui caractérise les événements. La discussion montre l'inadéquation de l'étiquette "parfait intensif » et propose une analyse fondée sur les liens entre l'intensification, la réduplication et la pluractionnalité. On fera valoir que l'intensité peut être abordée dans le cadre de la pluralité d'événements et qu'un nombre d'exemples avec des parfaits " anormaux » peuvent trouver une explication unificatrice lorsqu'ils sont interprétés comme exprimant différents types de valeurs pluractionnelles. Les cartes sémantiques illustrant les intersections entre les parcours diachroniques de la réduplication et le domaine de la pluralité d'événements clarifieront les fonctions et l'évolution des parfaits homériques.

\section{INDEX}

Mots-clés: intensité, réduplication, pluractionnalité, parfait, grec ancien

Keywords: intensity, reduplication, pluractionality, perfect, ancient Greek 